\title{
LEAF DAMAGE AND ASSOCIATED CUES INDUCE AGGRESSIVE ANT RECRUITMENT IN A NEOTROPICAL ANT-PLANT
}

\author{
Anurag A. Agrawal ${ }^{1}$ \\ Center for Population Biology, University of California, Davis, California 95616 USA
}

\begin{abstract}
Induced chemical responses following herbivory are common in plants. Plant responses that change the level of physical or biotic defense are less well documented and poorly understood. Many Azteca spp. ants are obligate inhabitants of Cecropia spp. trees. In such ant-plant associations the ants are thought to be analogous to chemical defenses; previous experiments have demonstrated that ant occupation of $C$. obtusifolia reduced herbivory and plant competition and increased growth. Experiments, conducted over two years, on the dynamics of ant defense demonstrate that leaf damage caused a fivefold increase in the number of Azteca spp. ants on damaged leaves of C. obtusifolia compared to that on disturbed but undamaged control leaves. Ant activity peaked 8-12 min after damage, and differences between damaged and control leaves remained evident for $24 \mathrm{~h}$. Such rapid induction of ant recruitment is likely to be particularly effective against unpredictable and mobile herbivores. The magnitude of the induced ant response to damage was strongly correlated with the number of ants patrolling the leaves before damage occurred. Ant responses to disturbance were not influenced by the presence of damage that had been applied $24 \mathrm{~h}$ previously. However, ant responses to subsequent damage, $24 \mathrm{~h}$ after initial damage, resulted in greater recruitment than to previously undamaged leaves.

Ant recruitment to several other cues associated with herbivory was also tested. Presence of pyralid caterpillars that naturally feed on $C$. obtusifolia induced a low level of ant recruitment, and most larvae were removed from leaves by the ants within $10 \mathrm{~min}$. Exposure to plant sap collected from damaged conspecifics and a commercially available green leaf volatile (hexanal) commonly released by plants after damage, both resulted in a doubling of ant numbers relative to controls. However, the levels of recruitment in response to these stimuli were insufficient to account for the high numbers of ants and persistence of recruitment observed on experimentally damaged leaves. Experimental wounding of leaves with minimal leaf tissue removal (using pin pricks) revealed that leaf wounds per se can only partially explain the induced ant recruitment following leaf damage. The type of herbivory and size of leaf wounds may be important cues for ant recruitment. Severed $C$. obtusifolia leaves that were freshly damaged failed to elicit an induced ant response when held adjacent to conspecific leaves with ants. However, induction of ant recruitment on damaged plants did significantly induce a low level of ant recruitment on neighboring conspecifics, providing evidence for interplant communication. Induced ant responses in the Cecropia-Azteca system are the result of multiple physical and chemical cues associated with herbivory. Ant responses to herbivory, although not previously studied in detail, are likely to be common among myrmecophytic plants and are likely to be an important component of antiherbivore defense in such systems.
\end{abstract}

Key words: Antiherbivore defense; ant-plant interactions; ant recruitment; Azteca; Cecropia; Costa Rica; hexanal; induced resistance; interplant communication; mutualism; plant-insect interactions; plant cues.

\section{INTRODUCTION}

Induced defensive responses to herbivory appear to be nearly ubiquitous in plants (Schultz 1988, Karban and Myers 1989, Karban and Baldwin 1997). In addition to induction of chemical (Baldwin 1994) and physical (Young 1987, Baur et al. 1991) defenses, for

Manuscript received 23 April 1997; revised 14 July 1997; accepted 31 August 1997; final version received 22 September 1997.

${ }^{1}$ Present address: Department of Entomology, One Shields Avenue, University of California, Davis, California 956168584 USA. many plants herbivory induces emission of de novo produced volatile compounds that attract natural enemies of herbivorous arthropods (Dicke et al. 1990, Turlings et al. 1990, Whitman and Eller 1990, Takabayashi and Dicke 1996, Pare and Tumlinson 1997). Induced responses in plants that feed and house mutualist defenders (e.g., ant-plants), however, have been little studied (but see Fiala and Maschwitz 1990, Cronin 1998). If mutualist ants are analogous to defensive secondary compounds as proposed by Janzen (1966), Rehr et al. (1973), McKey (1984, 1988), and others, there should be a well-developed rapidly induced response 
syndrome in tightly evolved ant-plant systems, especially where herbivory is unpredictable (see Zangerl and Rutledge 1996). I tested this prediction for the well-known mutualism between Cecropia obtusifolia (Moraceae) trees and ants in the genus Azteca.

Defense by ants in ant-plant systems has largely been viewed as a static process (but see Tilman 1978, Letourneau 1983, Cronin 1998; A. A. Agrawal and M. T. Rutter, unpublished manuscript). Defense of plants by ants has been studied most often by one of two methods: (1) ant removal experiments (e.g., Janzen 1966, Schupp 1986, Vasconcelos 1991, Fisher 1992, Fonseca 1994), and (2) study of the production of ant rewards (e.g., Risch and Rickson 1981, Steward and Keeler 1988, Koptur 1989, 1992, Smith et al. 1990, Davidson and Fisher 1991, Folgarait et al. 1994, Folgarait and Davidson 1995, Frias and Dirzo 1996). This body of work has demonstrated that ants often defend plants and have the potential to increase plant fitness. Although few studies have tested the dynamic nature of ant defense, some authors have speculated that ant responses are inducible (Koptur 1989, Smith et al. 1990; A. A. Agrawal and M. T. Rutter, unpublished manuscript). Previous studies, however, have focused on potential mechanisms for induced responses, such as increased attractiveness or additional production of extrafloral nectar; previous studies have not focused on induction of defending ants patrolling near damaged sites (but see Fiala and Maschwitz 1990). There are many biotic and abiotic components of the ant's and the plant's environment that can have important consequences for the induction and persistence of patrolling by ants (reviewed by A. A. Agrawal and M. T. Rutter, unpublished manuscript). I speculate that antplants often employ ants as induced defenses. Defending ants are ideal inducible defenses because of their mobile, rapidly deployable, and recoverable nature.

The significance of ants as an induced biotic defense is manifold. Induced chemical response systems include rapidly induced responses, operating over minutes to hours, and delayed induced responses, operating over weeks to years (Clausen et al. 1991, Haukioja 1991, Tallamy and McCloud 1991). Many induced ant responses in ant-plant systems may be analogous to rapidly induced chemical responses, and effective against mobile herbivores that can damage plants over a short period. Alternatively, delayed induced responses may also be common, influencing the longer term growth of an ant colony (see Passera et al. 1996). Ant-plants may also employ other delayed induced responses (chemical or otherwise) that are more effective against predictable subsequent attackers (see Karban and Adler 1996; A. A. Agrawal and M. T. Rutter, unpublished manuscript). Induced chemical responses can be highly localized (Olson and Roseland 1991, Zangerl and Berenbaum 1994/5) or systemic, changing throughout the whole plant (Baldwin 1994, Pare and Tumlinson 1997). Such responses potentially have different consequences for the plant. For example, rapidly induced localized responses may serve to make the herbivore flee the plant or at least disperse herbivore damage over different portions of the plant (Marquis 1996). Systemic responses may serve to protect the whole plant, but may be more delayed in nature, and if delayed they are also dependent on the predictability of future herbivory (Karban and Adler 1996). Localized and systemic responses are not mutually exclusive and are often found in the same system (Clausen et al. 1991, Haukioja 1991).

Several cues could be responsible for rapidly induced responses in biotically and chemically defended plants. Leaf damage alone does not always simulate herbivory (Baldwin 1990, Turlings et al. 1990). Cues associated with the herbivores, including disturbance, pattern of feeding, and saliva may influence the plant response. Similarly, different aspects of plant damage, including emission of volatiles (Takabayashi and Dicke 1996), exudation of plant sap (Naganuma and Hespenheide 1988, Dussourd and Denno 1994, McCloud et al. 1995, Jolivet 1996), and visual signs of herbivory (Niemela and Tuomi 1987) may directly or indirectly affect subsequent preference or performance of herbivores. In addition, plant cues may affect the defensive phenotype and response of neighboring plants (Baldwin and Schultz 1983, Rhoades 1983, Farmer and Ryan 1990, Bruin et al. 1995, Shonle and Bergelson 1995, Shulaev et al. 1997). Studies of interplant communication are rarely conducted in the field and have not been repeatable.

Cues associated with herbivory are likely to be especially important for biotically defended plants because the plant defenders must recognize and recruit to the damage site. Previous damage itself may be a cue for rapid recruitment of biotic defenders; for example, ants may be poised to recruit more strongly to previously damaged plants than to undamaged plants. Such an association could facilitate "memory" as a component of the induced response. Memory is an important component of animal immune responses and has been recently reported in an induced plant chemical response (Baldwin and Schmelz 1996). In biotically defended plants the mechanism of memory could be a more rapidly induced emission of plant cues, or could be based within the ants themselves (i.e., existing pheromonal trails or alarm motivation). In either case, memory could be important, even in systems with mobile and ephemeral herbivores, if certain parts of the plant will be predictably attacked or if dispersion of herbivory is beneficial to the plant (see Marquis 1996).

In this paper I report the results of experiments conducted over two years that tested the hypothesis that ant defense of host plants in the Cecropia-Azteca system is induced by cues associated with herbivory. Specifically I asked: (1) Does simulated herbivore damage induce localized ant recruitment to the leaves with damage; (2) What is the time course of induction of ant recruitment and relaxation of patrolling following foliar damage; (3) Does ant recruitment result after fresh damage only, rath- 


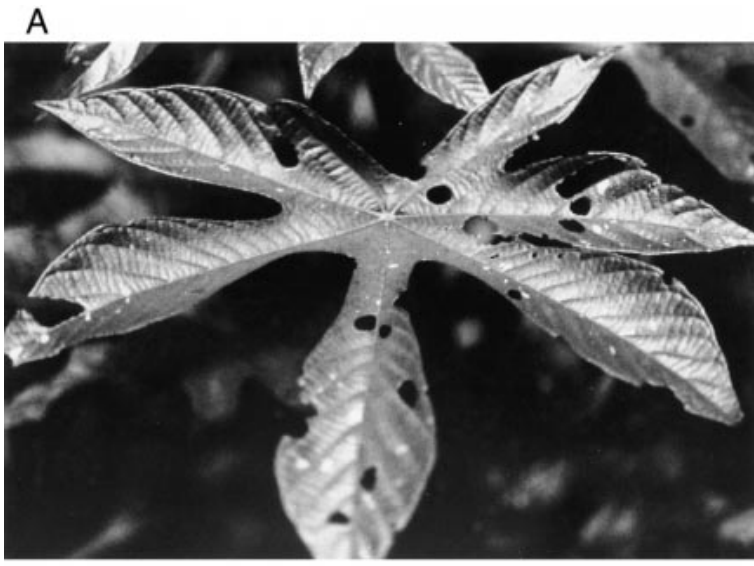

B

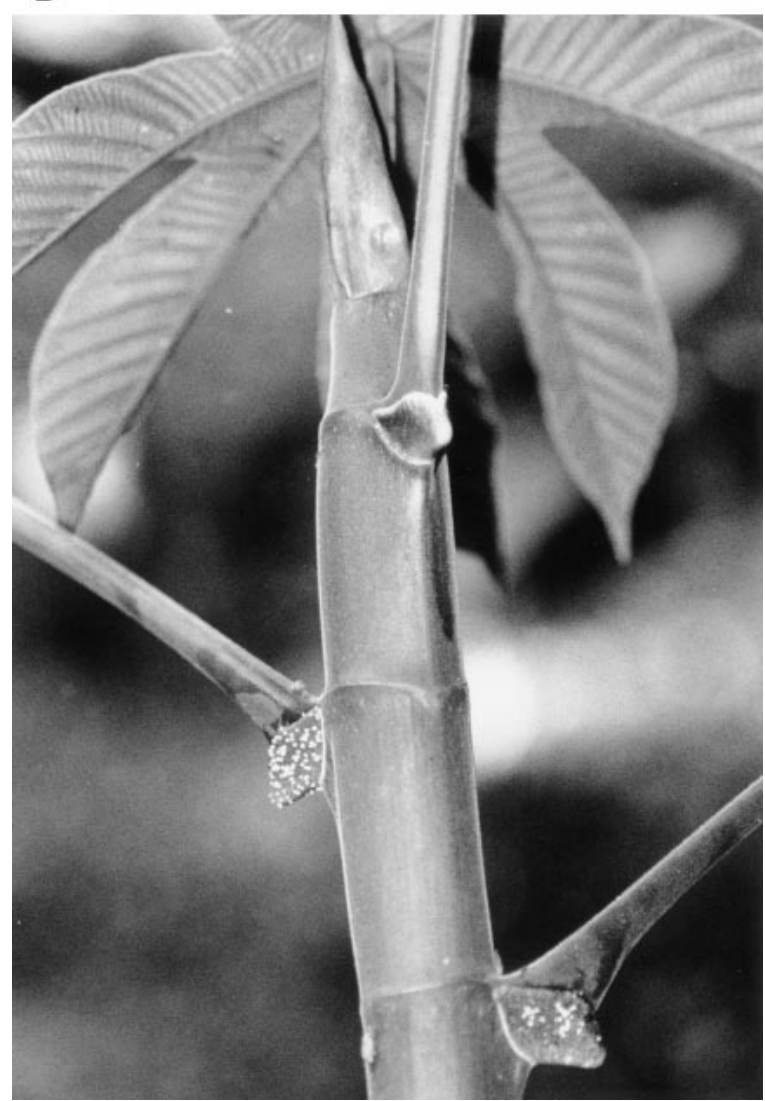

FIg. 1. A young Cecropia obtusifolia tree at La Selva Biological Station, Costa Rica. (A) This tree, although inhabited by ants, showed signs of herbivory by orthopterans. Such damage was commonly found on young $C$. obtusifolia and was experimentally simulated in this study by using a hole puncher. (B) A different tree was not inhabited by ants and was producing Müllerian food bodies on the trichilia at the base of the petioles.

er than disturbance or previous damage; (4) Does the induction of ant recruitment have a component of memory, whereby new damage to a previously damaged leaf results in a faster or greater ant response than to pre- viously undamaged leaves; (5) What is the time course of ant recruitment to a herbivore; (6) How do ants respond to different cues that are associated with leaf damage (plant sap, green leaf volatiles, and visual and tactile cues); and last (7) Is there any evidence for interplant communication, whereby a damaged plant with elevated numbers of ants influences ant patrolling on closely neighboring plants.

\section{Materials and Methods \\ Study site and organisms}

This study was conducted in July 1995 and September 1996, at the Organization for Tropical Studies, La Selva Biological Station, near the town of Puerto Viejo de Serapiquí, Heredia Province, Costa Rica. All study organisms were located within $100 \mathrm{~m}$ of the $6-\mathrm{km}$ Sendero Tres Rios trail. This is a frequently disturbed habitat, since station workers clear plants along the path. Further information about the site and climate is provided in McDade et al. (1994).

I studied the induction of ant recruitment following foliar damage in the native neotropical ant-plant $C$. obtusifolia (Fig. 1). Azteca (Dolichoderinae) ants inhabit most of the $C$. obtusifolia trees at La Selva. The mutualism between Cecropia spp. and Azteca spp. has been intensively studied and the nature of the relationship is well known (Janzen 1969, 1973, Schupp 1986, Longino 1989, 1991, Jolivet 1990, Davidson and Fisher 1991, Rocha and Bergallo 1992, Folgarait and Davidson 1995, Vasconcelos and Casimiro 1997). Like almost all members of the genus Cecropia, $C$. obtusifolia has a hollow stem and produces Müllerian and pearl food bodies (A. A. Agrawal, personal observation). Azteca ants consume the food bodies, raise their brood in the hollow stems, patrol the plant and, in many cases, successfully reduce herbivory and increase the fitness of plants relative to conspecifics without ant protectors (Schupp 1986, Rocha and Bergallo 1992, Vasconcelos and Casimiro 1997). Schupp (1986) demonstrated that $C$. obtusifolia without its ant inhabitants experienced higher herbivory, increased vine cover, and significantly stunted growth. I studied young $C$. obtusifolia trees inhabited by $A$. xanthocroa or $A$. constructor. Both ant species are extremely aggressive defenders of Cecropia spp. and are difficult to distinguish without examining the queen (J. Longino, personal communication). Worker ants were sampled from each tree to make sure that the ants were not $A$. alfari, the apparently less aggressive and less defensive species of Azteca ant that inhabits Cecropia spp. (Longino 1991, but see Vasconcelos and Casimiro 1997). The latter species can be easily distinguished by examining workers (J. Longino, personal communication). Azteca xanthocroa and A. constructor are both obligate mutualists with Cecropia spp.

\section{Ant responses to damage}

To test if ants would rapidly recruit to sites of foliar damage, I monitored ant numbers on experimentally 
damaged and control leaves of $C$. obtusifolia using a paired-leaf design. In 1995, I selected 15 young trees between 1.5 and $2.5 \mathrm{~m}$ tall, lacking signs of recent herbivory, and with established colonies of A. xanthocroa or A. constructor. On each tree, I haphazardly chose two of the youngest, fully expanded leaves coming off the main stem ( $\sim 1-2 \mathrm{~m}$ apart) and randomly assigned one to the "damaged" treatment and one to the "undamaged control" treatment. I censused the number of ants on the leaves prior to imposing the treatment.

Immediately after the initial census I simulated herbivory by punching five holes $\left(\sim 30 \mathrm{~mm}^{2}\right.$ each $)$ in each lobe of the damaged leaf. Natural herbivory by generalist orthopterans often results in small bullet-like holes very similar to those created by a hole puncher (Fig. 1A). Each leaf consisted of 7-12 lobes, and had a total area $<0.25 \mathrm{~m}^{2}$. The control leaf was disturbed in a very similar way to the damaged leaf: it was shaken (by tapping with the hole puncher) for an equal length of time and with equal disturbance as the damaged leaf. I also clicked the hole puncher in the air next to the leaf so the sound was present in both treatments. The only difference was that the holes were not actually made in the control treatment leaf. I randomly chose which treatment to execute first on each tree. I made visual censuses of ants at 4, 8, 12, 16, and $20 \mathrm{~min}$, and at 1, 2, 4, and $\sim 24 \mathrm{~h}$ after the manipulation. I repeated this experiment in 1996 with 24 additional trees, using identical procedures.

To test whether ants would recruit to previous sites of damage (without further leaf wounding), I heavily disturbed both previously damaged leaves and control leaves by vigorously shaking the petioles after the 24h census in 1995 ( $n=11$ pairs). This tested the hypothesis that ants only recruit to recently damaged leaves, and that disturbance to a previously damaged leaf would not induce greater recruitment than disturbance to an undamaged leaf. Ants were censused before the disturbance and again 5 min after the disturbance.

\section{Memory of the induced response}

To test if ants recruit faster or in greater abundance to sites of previous damage, I conducted experiments on the set of trees used in the experiments in 1996 (see Materials and Methods: Ant responses to damage). Twenty-four hours after the leaves were initially treated and ant recruitment had relaxed nearly to control levels, I initiated the memory experiment. Both previously damaged leaves and control leaves received five hole punches per lobe. Ants were censused before the manipulation and again at 4, 8, and 12 min after the treatment. My prediction was that if the ant response had memory, recruitment would be faster on a previously damaged leaf, or would result in higher levels of recruitment than on a previously undamaged leaf.

\section{Ant recruitment to herbivores}

In this experiment I tested whether ants recruit to the mere presence of a herbivore (not herbivory, a pyralid moth caterpillar that commonly feeds on $C$. $o b$ tusifolia [L. Dyer, personal communication]). Fourth or fifth instar caterpillars of the unidentified species of leaf rollers were collected from several young $C$. obtusifolia trees that lacked ants. On each of 19 trees with ants, ant numbers were censused on two randomly chosen undamaged leaves prior to the experimental treatments, then one caterpillar was laid onto the leaf surface on one of the leaves, and a small twig the size of a caterpillar was placed on the other leaf. Ants were censused at 4, 8, 12, 16, and $20 \mathrm{~min}$ and $1 \mathrm{~h}$ after manipulation. If the caterpillar or twig was removed from the leaf by the patrolling ants, the time when this occurred was noted.

\section{Mechanisms of the induced response}

Plant chemical cues. - To test if ants were recruiting to plant cues, I measured the recruitment that followed elicitation using plant sap, a common green leaf volatile found in many plants, and unidentified volatile cues from severed damaged leaves. Previous anecdotal observations of $C$. obtusifolia and other myrmecophytic plants suggested that ants may be drinking plant sap at sites of damage (A. A. Agrawal, personal observation; M. T. Rutter and J. Longino, personal communication; see also Naganuma and Hespenheide 1988, Jolivet 1996). Plant sap experiments were conducted by collecting plant sap from damaged $C$. obtusifolia trees not used in the experiments and blotting sap onto $1-\mathrm{cm}^{2}$ squares of filter paper. On 21 trees I placed one piece of filter paper soaked in plant sap on a randomly selected leaf and an equal-sized square of filter paper soaked in water on an adjacent leaf. Ants were censused before and at 4, 8, and 12 min after adding the squares of filter paper.

A similar paired-leaf design experiment was conducted using the green leaf volatile, hexanal (Sigma Chemical Company, St. Louis, Missouri). Hexanal is an aromatic compound often released from damaged green leaves (Whitman and Eller 1990). Such compounds have been implicated in plant attractiveness to natural enemies of herbivores (Whitman and Eller 1990, Takabayashi and Dicke 1996). On each of 21 trees, one randomly chosen leaf received a square of filter paper with one drop of hexanal and an adjacent leaf received a square of filter paper with one drop of water. Ants were censused before and at 4, 8, and 12 min after adding the squares of filter paper.

A third experiment was conducted to test if unidentified volatile constituents from damaged C. obtusifolia leaves would induce ant recruitment on assay leaves. Leaves on intact $C$. obtusifolia trees were damaged with a hole puncher ( 5 holes/lobe) and after a few minutes the damaged leaf and undamaged control were removed 


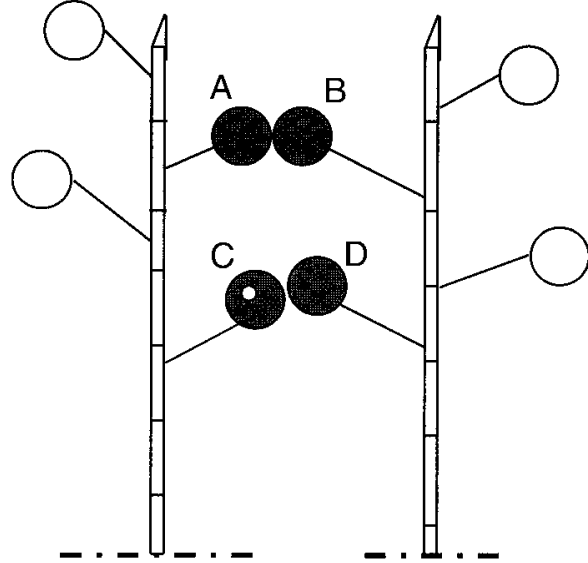

FIG. 2. Schematic diagram of the experimental design used to test for evidence of interplant communication. Leaf A was disturbed (not damaged), and leaf $\mathrm{C}$ was damaged. Ant responses were then measured and compared on the "listen leaves" B and D.

at the base of the petiole. All ants were picked off the leaves by hand. I then took these leaves to an assay $C$. obtusifolia tree and simultaneously held the cut leaves as close as possible (without touching, but no farther than $5 \mathrm{~cm}$ ) next to two unmanipulated assay leaves. Ants were censused before the experiment began and at 4 and 8 min after starting to hold experimental leaves next to assay leaves. Cut leaves were only used once. The experiment was replicated with 15 assay trees.

Visual and tactile cues.-To test whether the persistent ant recruitment induced by foliar damage was due to visual or tactile cues, I attempted to damage leaves without a detectable loss of leaf area. By lodging 50 insect pins through a small block of styrofoam, I constructed a device to deliver a large number of tiny foliar wounds. On each of 24 plants I randomly assigned two undamaged leaves to receive either: (1) one pin press per lobe (7-12 lobes, $\sim 500$ pin holes total) or (2) undamaged controls that were disturbed by clapping the leaf with the styrofoam side of the pin press. Ants were censused prior to manipulation and at 4,8 , 12,16 , and $20 \mathrm{~min}$ afterwards.

\section{Interplant communication and ant-borne signals}

Here I tested the hypothesis that cues emanating from a damaged plant induce biotic defenses in undamaged neighbors. To test if induced ant recruitment on one tree would cause closely neighboring trees to have elevated ant activity, I selected 15 pairs of trees growing together with leaves that were within $5 \mathrm{~cm}$ of each other. Two pairs of touching or nearly touching leaves were selected for each pair of plants (Fig. 2). Because ant recruitment is very localized in this system (see Fig. 3), each pair of leaves was considered independent. The first pair (A, B) was randomly chosen to serve as the control pair: leaf A was disturbed but not damaged and ants were censused on both leaves before and 4 ,
$8,12,16$, and $20 \mathrm{~min}$ after the treatment. The second pair of leaves $(C, D)$ was the treatment pair: leaf $C$ was damaged as in the previous experiments, by punching five holes in each lobe, and ants were censused on both leaves before and 4, 8, 12, 16, and $20 \mathrm{~min}$ after the treatment. To test for interplant communication, leaves $\mathrm{B}$ and D were compared to see if ants on the "listen tree" recruited to leaves next to damaged leaves and not to leaves next to disturbed leaves.

\section{Statistical analysis}

All analyses were conducted using the MGLH routine in Systat (Wilkinson et al. 1992). All experiments were conducted with a paired design, where each tree or experimental unit had both treatments, with no replication within each unit. Repeated measures analysis of variance procedures were used to test for treatment effects in all experiments except in the ant response to disturbance experiment in which a paired $t$ test was used. Treatments were considered fixed effects and tree was considered a random effect. In such designs, the between-subjects (remainder) mean square and degrees of freedom are used in the denominator to calculate the $F$ statistic (Zar 1996:267). In all ant recruitment trials the first census (time 0) was conducted immediately prior to treatment and was strictly used to verify that

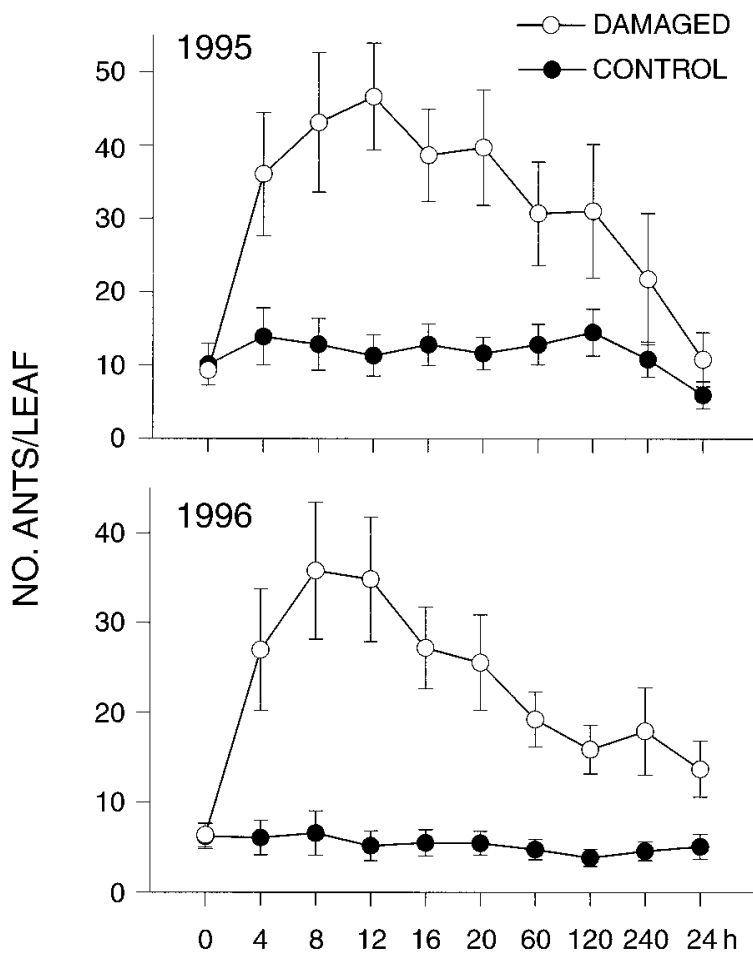

\section{TIME (MINUTES)}

FIG. 3. Time course of ant recruitment to leaves damaged by punching holes vs. undamaged (disturbed) controls for experiments conducted over two years. 
TABLE 1. Repeated-measures ANOVAs for the effects of induction treatments on ant recruitment.

\begin{tabular}{|c|c|c|c|c|c|c|c|}
\hline Experiment & Source & df & MS & $F$ & $P$ & G-G & $\mathrm{H}-\mathrm{F}$ \\
\hline Time-course 1995 & $\begin{array}{l}\text { Treatment } \\
\text { Error } \\
\text { Time } \\
\text { Time } \times \text { Treatment } \\
\text { Error }\end{array}$ & $\begin{array}{r}1 \\
14 \\
8 \\
8 \\
112\end{array}$ & $\begin{array}{r}30549.57 \\
2542.25 \\
1321.49 \\
719.21 \\
105.92\end{array}$ & $\begin{array}{r}12.01 \\
12.48 \\
6.79\end{array}$ & $\begin{array}{l}<0.001 \\
<0.001\end{array}$ & $\begin{array}{l}<0.001 \\
<0.001\end{array}$ & $\begin{array}{l}<0.001 \\
<0.001\end{array}$ \\
\hline Time-course 1996 & $\begin{array}{l}\text { Treatment } \\
\text { Error } \\
\text { Time } \\
\text { Time } \times \text { Treatment } \\
\text { Error }\end{array}$ & $\begin{array}{r}1 \\
23 \\
8 \\
8 \\
184\end{array}$ & $\begin{array}{r}38552.22 \\
1629.74 \\
884.95 \\
656.60 \\
96.09\end{array}$ & $\begin{array}{l}9.21 \\
6.83\end{array}$ & $\begin{array}{l}<0.001 \\
<0.001 \\
<0.001\end{array}$ & $\begin{array}{r}<0.001 \\
0.001\end{array}$ & $\begin{array}{l}<0.001 \\
<0.001\end{array}$ \\
\hline Memory & $\begin{array}{l}\text { Treatment } \\
\text { Error } \\
\text { Time } \\
\text { Time } \times \text { Treatment } \\
\text { Error }\end{array}$ & $\begin{array}{r}1 \\
23 \\
2 \\
2 \\
46\end{array}$ & $\begin{array}{r}6413.34 \\
724.75 \\
50.90 \\
426.92 \\
75.873\end{array}$ & $\begin{array}{l}8.85 \\
\\
0.67 \\
5.63\end{array}$ & $\begin{array}{l}0.007 \\
0.516 \\
0.007\end{array}$ & $\begin{array}{l}0.491 \\
0.01\end{array}$ & $\begin{array}{l}0.516 \\
0.007\end{array}$ \\
\hline Recruitment to Pyralid caterpillar & $\begin{array}{l}\text { Treatment } \\
\text { Error } \\
\text { Time } \\
\text { Time } \times \text { Treatment } \\
\text { Error }\end{array}$ & $\begin{array}{r}1 \\
18 \\
5 \\
5 \\
90\end{array}$ & $\begin{array}{r}338.97 \\
82.42 \\
12.42 \\
16.77 \\
9.76\end{array}$ & $\begin{array}{l}4.11 \\
\\
1.27 \\
1.717\end{array}$ & $\begin{array}{l}0.058 \\
\\
0.283 \\
0.139\end{array}$ & $\begin{array}{l}0.294 \\
0.177\end{array}$ & $\begin{array}{l}0.283 \\
0.139\end{array}$ \\
\hline Plant sap & $\begin{array}{l}\text { Treatment } \\
\text { Error } \\
\text { Time } \\
\text { Time } \times \text { Treatment } \\
\text { Error }\end{array}$ & $\begin{array}{r}1 \\
20 \\
2 \\
2 \\
40\end{array}$ & $\begin{array}{r}516.07 \\
38.09 \\
10.72 \\
6.88 \\
3.75\end{array}$ & $\begin{array}{r}13.55 \\
\\
2.86 \\
1.84\end{array}$ & $\begin{array}{l}0.001 \\
0.069 \\
0.173\end{array}$ & $\begin{array}{l}0.072 \\
0.175\end{array}$ & $\begin{array}{l}0.069 \\
0.173\end{array}$ \\
\hline Green leaf volatiles & $\begin{array}{l}\text { Treatment } \\
\text { Error } \\
\text { Time } \\
\text { Time } \times \text { Treatment } \\
\text { Error }\end{array}$ & $\begin{array}{r}1 \\
20 \\
2 \\
2 \\
40\end{array}$ & $\begin{array}{r}557.34 \\
29.79 \\
23.01 \\
16.44 \\
8.01\end{array}$ & $\begin{array}{r}18.71 \\
\\
2.87 \\
2.05\end{array}$ & $\begin{array}{r}<0.001 \\
\\
0.068 \\
0.142\end{array}$ & $\begin{array}{l}0.077 \\
0.149\end{array}$ & $\begin{array}{l}0.068 \\
0.142\end{array}$ \\
\hline Damaged cut leaf & $\begin{array}{l}\text { Treatment } \\
\text { Error } \\
\text { Time } \\
\text { Time } \times \text { Treatment } \\
\text { Error }\end{array}$ & $\begin{array}{r}1 \\
14 \\
2 \\
2 \\
28\end{array}$ & $\begin{array}{r}13.61 \\
1.75 \\
35.83 \\
0.21 \\
2.85\end{array}$ & $\begin{array}{r}7.76 \\
12.57 \\
0.07\end{array}$ & $\begin{array}{r}0.015 \dagger \\
<0.001 \\
0.929\end{array}$ & $\begin{array}{l}0.001 \\
0.855\end{array}$ & $\begin{array}{r}<0.001 \\
0.929\end{array}$ \\
\hline Pin wounds & $\begin{array}{l}\text { Treatment } \\
\text { Error } \\
\text { Time } \\
\text { Time } \times \text { Treatment } \\
\text { Error }\end{array}$ & $\begin{array}{r}1 \\
23 \\
4 \\
4 \\
92\end{array}$ & $\begin{array}{c}288.20 \\
59.09 \\
46.80 \\
26.10 \\
9.530\end{array}$ & $\begin{array}{l}4.88 \\
\\
4.91 \\
2.74\end{array}$ & $\begin{array}{l}0.037 \\
0.001 \\
0.033\end{array}$ & $\begin{array}{l}0.013 \\
0.078\end{array}$ & $\begin{array}{l}0.001 \\
0.033\end{array}$ \\
\hline Interplant communication & $\begin{array}{l}\text { Treatment } \\
\text { Error } \\
\text { Time } \\
\text { Time } \times \text { Treatment } \\
\text { Error }\end{array}$ & $\begin{array}{r}1 \\
14 \\
4 \\
4 \\
56\end{array}$ & $\begin{array}{r}110.94 \\
23.80 \\
4.48 \\
3.09 \\
3.00\end{array}$ & $\begin{array}{l}1.49 \\
1.03\end{array}$ & $\begin{array}{l}0.049 \\
0.217 \\
0.400\end{array}$ & $\begin{array}{l}0.239 \\
0.378\end{array}$ & $\begin{array}{l}0.217 \\
0.400\end{array}$ \\
\hline
\end{tabular}

Note: Probabilities corrected for sphericity are provided using the Greenhouse-Geisser (G-G) and Huyn-Feldt (H-F) corrections.

$\dagger$ This difference, although statistically significant, does not reflect a treatment effect. Differences were apparent before treatments were imposed (no time $\times$ treatment interaction, even when time 0 is included in the analysis).

there were not differences between leaves prior to treatment. Similar analyses using MANOVA and profile analysis yielded the same conclusions. Only repeatedmeasures analysis of variance are reported (Table 1). All error bars shown in the graphs are standard errors of the mean. Data were transformed if necessary to meet the assumptions of normality and equal variances.

\section{RESULTS}

\section{Ant responses to damage}

Ant recruitment to artificially damaged leaves was much greater than to control leaves on the same tree in both years of this study (Fig. 3). Induction of re- cruitment was rapid and localized. The ant recruitment seen in these experiments demonstrates the importance of leaf damage per se, as disturbance without damage elicited minimal change in ant activity (Fig. 3). In both years, ant recruitment peaked between 8 and 12 min after leaves were damaged. Up to 150 ants per leaf were counted during peak recruitment. After $24 \mathrm{~h}$ ant levels relaxed to nearly premanipulation levels.

The number of ants patrolling leaves before damage was a good predictor of ant recruitment following damage (Fig. 4). Plants with high levels of ants before damage had higher subsequent ant recruitment than plants that started out with lower numbers of ants. This 


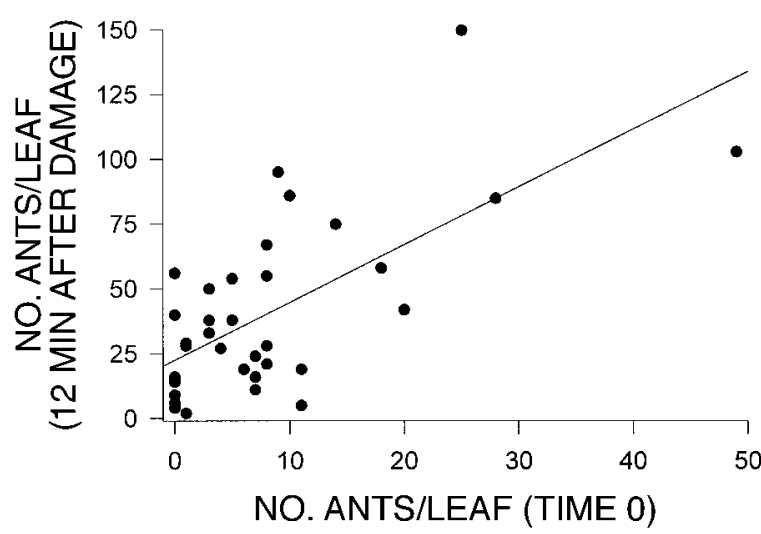

FIG. 4. Number of ants per leaf 12 min after damage (during peak ant recruitment) plotted against number of ants before damage for individual leaves on 39 trees (pooled for 1995 and 1996). Linear regression: $R^{2}=0.424, Y=23.128$ $+2.164 X, F_{1,37}<0.001$. Only 35 points show because of overlap.

is consistent with the observation of lower average peak recruitment in 1996 (35 ants/leaf) vs. 1995 (45 ants/leaf) because ant numbers before damage were lower in 1996 than 1995.

\section{Disturbance and memory}

Disturbance (without damage) to the petioles of leaves that had been damaged $24 \mathrm{~h}$ earlier did not cause higher or more rapid ant recruitment than did similar disturbance to control leaves not receiving prior damage (Fig. 5). Surprisingly, fewer than 15 ants per leaf were observed following the disturbances, suggesting that even severe disturbance does not induce the magnitude of recruitment observed after foliar damage. In addition, this trial shows that ants do not recruit to the presence of damage unless it is fresh, suggesting that only cues associated with fresh leaf damage induce recruitment.

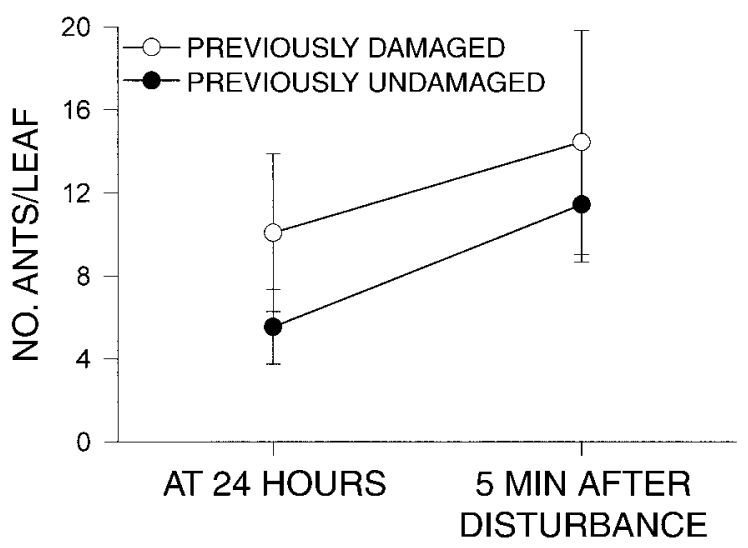

FIG. 5. Recruitment of ants to paired leaves that were heavily disturbed; one leaf was previously undamaged, and the other was damaged $24 \mathrm{~h}$ previously ( $t$ test: $t=-0.688$, df $=10, P=0.51)$

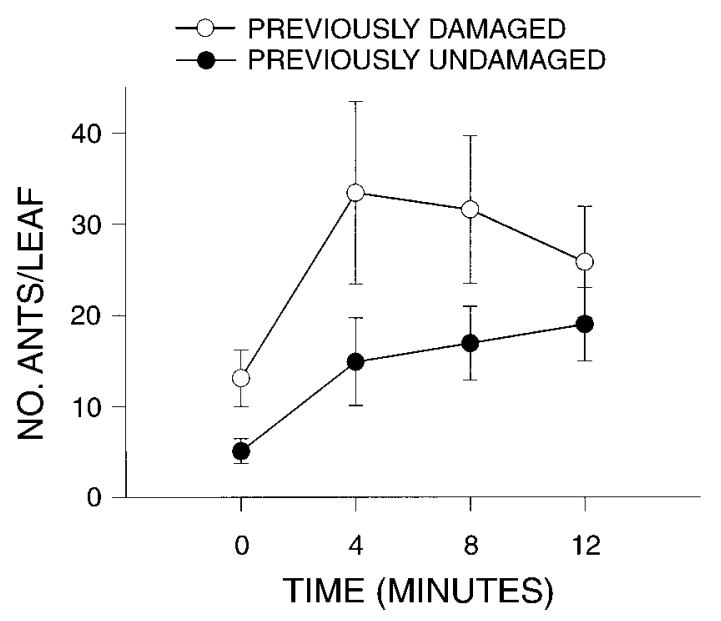

FIG. 6. Recruitment of ants to paired leaves that were damaged; one leaf was previously undamaged, and the other was damaged $24 \mathrm{~h}$ previously.

Induced ant recruitment to previously damaged leaves was greater than that to previously undamaged leaves (Fig. 6). Although ant recruitment was higher on previously damaged plants, initial levels of ant patrolling had not fully relaxed in previously damaged plants.

\section{Ant recruitment to herbivores}

There was a marginally significant effect of ant recruitment to the presence of a pyralid caterpillar (Fig. 7). Control leaves that were disturbed with a small twig of the same size as a caterpillar did not accumulate ants. In 2 of the 19 trials, the caterpillars sewed leaf rolls and subsequently were not bothered by Azteca ants. In all other trials the ants attacked the caterpillar as soon as they recognized it and drove it to the edge of the leaf until it dropped off the plant. In none of the

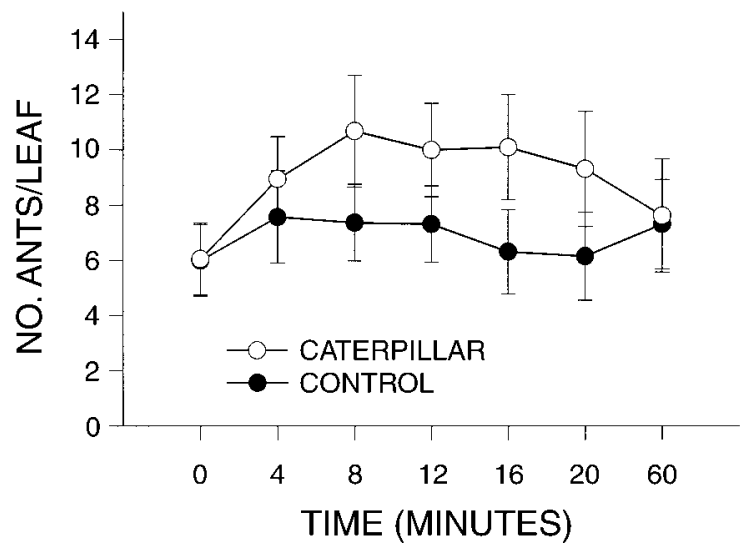

FIG. 7. Recruitment of ants to the presence of a pyralid moth caterpillar. Control leaves had a caterpillar-sized twig. The average time to eviction of the caterpillars was 7.24 \pm $2.27 \mathrm{~min}$. 

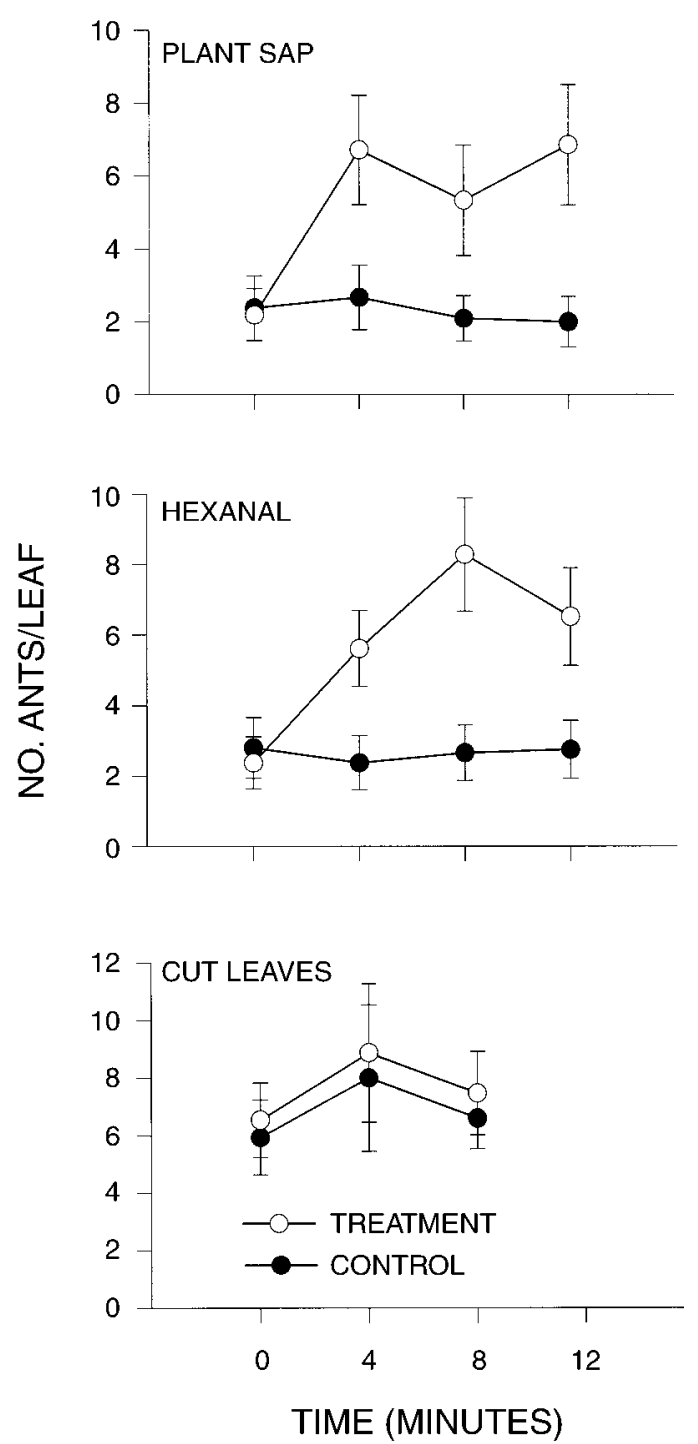

FIG. 8. Recruitment of ants to extracted plant sap, green leaf volatiles (hexanal), and volatiles emitted from a damaged severed conspecific leaf.

trials did the caterpillar commence feeding during the 1 -h period of monitoring.

Leaf damage is probably not necessary to induce ant recruitment. However, ant recruitment to the caterpillar did not usually exceed 30 ants per leaf (14 of 19 trials, Fig. 7). The magnitude of the response to herbivores was fourfold lower than to leaf damage (compare Figs. 3 and 7). This suggests that leaf damage is a more potent inducer of ant activity than presence of a herbivore. The signals associated with leaf damage may be more important cues because they may be more easily detected by ants than those produced by the herbivores themselves.

\section{Mechanisms of the induced response}

Plant chemicals.-More ants recruited to leaves with filter paper squares containing either plant sap or hex- anal than to control leaves with filter paper and water alone (Fig. 8). Although the numbers of ants prior to manipulation were low in both cases (three ants/leaf), peak ant responses to these cues were weak $(<$ eight ants/leaf) and declined too early to explain the magnitude of ant recruitment following actual leaf damage. I observed no difference in recruitment of ants to leaves adjacent to damaged leaves compared to recruitment on leaves adjacent to undamaged leaves in the experiment that used severed damaged and undamaged $C$. obtusifolia leaves to elicit ant recruitment on another tree (Fig. 8).

Visual and tactile cues.-Treating a leaf with several hundred pin wounds induced significant ant recruitment beyond the recruitment observed on paired leaves that were disturbed but not damaged (Fig. 9). In this experiment leaf wounds and the presumed associated volatile cues (quantification of the emitted volatiles was not possible) associated with damage were present; however, gaping holes in the leaves were not present. The magnitude of the response to pinning was fourfold lower than to leaf damage caused by holes being punched (compare Figs. 3 and 9).

\section{Interplant communication and ant-borne signals}

Leaves (listen D) next to damaged leaves (talk C) accumulated significantly more ants than did control leaves (listen B) next to disturbed but undamaged leaves (talk A) (Fig. 10, see also Fig. 2). I found evidence for interplant communication; induction of ant recruitment on a damaged plant resulted in induction on neighboring plants.

\section{DISCUSSION}

\section{Ant responses to damage}

Experiments conducted over two years indicate that Azteca ants rapidly recruit to localized sites of foliar damage on C. obtusifolia. This is the first detailed study

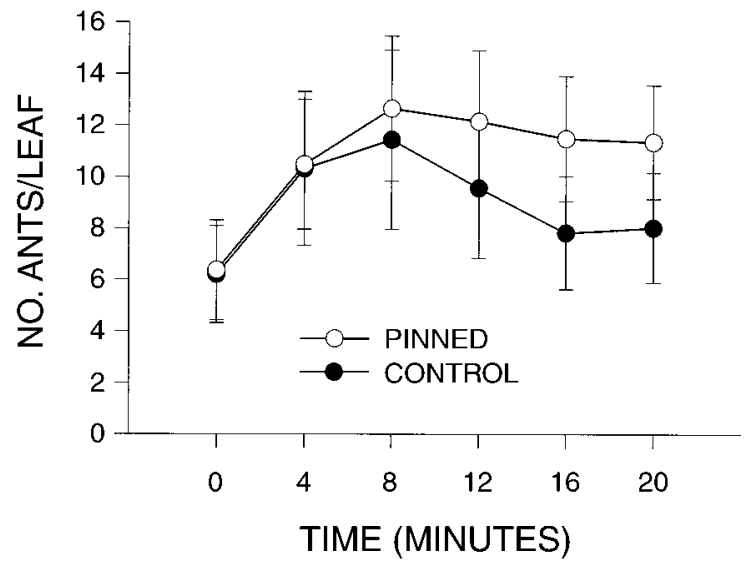

FIG. 9. Recruitment of ants to leaves with several hundred pin wounds compared to recruitment on paired leaves that were disturbed but not damaged. 


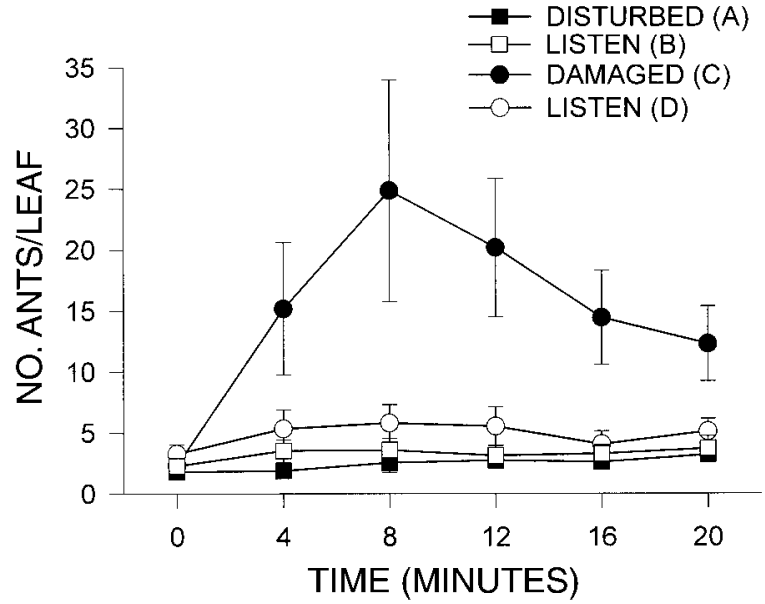

FIG. 10. Recruitment of ants on pairs of leaves of neighboring conspecifics (see Fig. 2. for experimental design), There were significantly more ants on listen leaves (D) next to damaged leaves (C) than on listen leaves (B) next to disturbed leaves (A).

of ant recruitment to sites of leaf damage in an antplant system (see also Fiala and Maschwitz 1990). Induction of ant recruitment depended on leaf damage and several associated cues. It should be noted that the ant responses measured in these experiments cannot necessarily be equated with resistance to herbivores and defense of the plants (Karban and Myers 1989: Table 1). However, Rocha and Bergallo (1992) found a negative correlation between number of Azteca ants patrolling Cecropia leaves and time to discovery of herbivores, residence time of invading herbivores, and plant damage. In addition, occupation of $C$. obtusifolia trees by Azteca ants did increase fitness of juvenile plants (Schupp 1986); further experiments will have to be conducted to determine if induction of ant recruitment per se deters herbivores, reduces herbivory, and increases plant fitness.

The positive relationship between "constitutive" levels of ant defense (number of ants before damage) and the magnitude of "induced" ant numbers (recruitment of ants following damage) is contrary to the predictions of theory (Herms and Mattson 1992), although it is consistent with the finding of workers who have measured other types of constitutive and induced resistance and found positive relationships between these two (Zangerl and Berenbaum 1990, Rocha and Bergallo 1992). Other workers have found no clear relationship between constitutive and inducible resistance (Brody and Karban 1992, Thaler and Karban 1997). The positive association between pre- and post-induction ant numbers may depend on colony size (i.e., Rocha and Bergallo 1992); trees with larger ant colonies may have more ants patrolling undamaged leaves as well as have more ants available for recruitment subsequent to damage. Communication between ants, which occurs in the recruitment process (presumably via pheromones), may also be an important cause of the association between ant numbers pre- and post-induction (see Fiala and Maschwitz 1990). Effects of colony size and inter-ant communication are not mutually exclusive.

If ants could function as induced responses generally, then defense by ants in myrmecophytic plants may be more dynamic than once thought. Costs and benefits of ant defense to plants depends on ant activity in addition to measurement of allocation to ant rewards such as food bodies or extrafloral nectar (Tilman 1978, Stephenson 1982, Koptur 1989, 1992, Smith et al. 1990, Davidson and Fisher 1991, Folgarait et al. 1994, Folgarait and Davidson 1995). If costs of ant defense were measured in the absence of herbivores (with and without ants), the costs may be obscured because the plants will never experience ants in the induced state (see also Rausher et al. 1993).

Induced ant recruitment in myrmecophytic plants is likely to be common. In obligate ant-plant associations where ant fitness is tightly linked to plant health, ant recruitment to damage may require no direct reward (A. A. Agrawal and M. T. Rutter, unpublished manuscript). Recruitment of Azteca ants to damaged C. obtusifolia leaves may be such an association. Extrafloral nectar is not secreted by $C$. obtusifolia and increased production of food bodies is not likely to act over the spatial and temporal scales necessary to induce the sort of recruitment seen in Fig. 3 (A. A. Agrawal, personal observations; B. Fisher, personal communication). Is Azteca fitness tightly linked to the vigor of the plant? Frias and Dirzo (1996) showed that $40 \%$ defoliation of C. obtusifolia in a controlled environment lacking ants did not reduce production of Müllerian food bodies over several weeks following treatment compared to undamaged controls. This suggests that $C$. obtusifolia supports its ant inhabitants (probably with food body production) even when levels of defoliation are high. C. obtusifolia may continue to produce food bodies because ant protection is crucial for plant survival. It is not known whether Frias and Dirzo's (1996) results are general. In more facultative associations damaged plants may have to increase reward production in order to recruit biotic defenders because facultative defenders do not necessarily rely on individual plants for housing and food.

Memory in immune responses is common among vertebrates; however it is unknown whether it is a general component of induced defense systems in invertebrates and plants (Harvell 1990a, b). In the current experiment ant induction was greater on previously damaged leaves than on previously undamaged leaves. However, the finding of memory in the ant responses (Fig. 6) may be an artifact of the positive relationship between initial ant numbers and level of the induced recruitment (Fig. 4). The initial numbers of ants on previously damaged leaves were higher than on previously undamaged leaves. This result further demonstrates that the pretreatment number of ants on in- 
dividual leaves can affect the level to which the ants will recruit. Karban and Niiho (1995) failed to find evidence of plant memory for induced resistance of cotton seedlings against spider mites. However, Baldwin and Schmelz (1996) did find that induction of nicotine accumulation was faster in previously damaged wild tobacco plants than in undamaged plants. Memory in an induced defense might not only minimize overall herbivory, but may also reduce areas of concentrated damage. Because spatial patterns of herbivory may have differential fitness effects for plants (Lowman 1982, Marquis 1992, 1996, Mauricio et al. 1993, Coleman and Leonard 1995), memory could serve the important function of dispersing herbivore damage.

\section{Mechanisms of the induced response}

Ants are likely recruiting to cues associated with leaf damage, such as the volatile constituents of plant sap and green leaf volatiles. Ants must be able to recognize host plants when colonizing the plants and especially when pruning encroaching vines (reviewed by Davidson and McKey 1993). This identification may largely be based in perceptions of volatile plant constituents and leaf damage may release many of these compounds (Fiala and Maschwitz 1990). I did not observe Azteca ants drinking plant sap at sites of damage, although this has been observed in other systems (Jolivet 1996; J. Longino and A. Fraser, personal communication). Although I tested for ant recruitment following exposure to one green leaf volatile (hexanal), many different volatiles and mixtures may be released following damage. It is unlikely, however, that chemical cues associated with leaf damage are solely responsible for the high magnitude and persistence of ant recruitment seen after leaf damage. Cut leaves did not induce ant recruitment when held next to intact plants with ants.

In non-ant-plant systems there is mounting evidence that cues released following damage are associated with recruitment of predators of herbivores (Dicke et al. 1990, Turlings et al. 1990, Whitman and Eller 1990, Takabayashi and Dicke 1996). For example, number of foraging formicine ants, Formica lasioides, increased significantly within $24 \mathrm{~h}$ on artificially damaged bush lupine, Lupinus arboreus, compared to undamaged controls (Wilcox 1996). Recent evidence demonstrates that some of these cues are volatiles produced de novo by the plant, suggesting that plants may play an active part in recruiting protectors (Pare and Tumlinson 1997). In addition, insect damage on Baccharis can produce nectary-like wounds that attract natural enemies of herbivores who drink the exuding sap (Naganuma and Hespenheide 1988). In these systems, it is presumed that the predators additionally benefit by finding prey items at wound sites. Such signals may also be important cues in more facultative ant-plant systems where the ants consume the herbivores attacking the host plant. In obligate systems such as the AcaciaPseudomyrmex (Janzen 1966) and Cecropia-Azteca as- sociations, ants do not consume herbivores found at the wounds, but rather attack and discard them (A. A. Agrawal, personal observation; J. Longino, personal communication). As discussed, plants may not have to entice their ant inhabitants to damaged leaves in increasingly obligate systems.

Puncturing $C$. obtusifolia leaves with pin holes resulted in elevated ant levels, although the magnitude of response was less than a twofold increase compared to disturbed but undamaged controls (Fig. 9). This result underscores the conclusion that chemicals associated with leaf damage can induce recruitment, but that leaf wounds alone, especially when made by small pins, are insufficient to explain induced ant recruitment to larger leaf wounds seen in this system (Fig. 3). I predict that visual and tactile cues associated with larger leaf wounds contribute significantly to the induction of high and persistent levels of ant recruitment.

Results of the experiment to test for interplant communication are contrary to the results of experiments using severed leaves, suggesting that cues from other ants may be more important than cues from plants in some aspects of ant recruitment. When both damaged leaves and induced ant recruitment were considered (interplant communication experiment), ants on neighboring control leaves increased in numbers. However, when damaged severed leaves (with ants removed) were held near control leaves, no induced recruitment was detected. Other work on interplant communication under field conditions is lacking, and it remains unknown whether plants commonly have an altered defensive phenotype because of signals from neighboring plants.

\section{CONCLUSION}

Leaf damage to $C$. obtusifolia and associated cues induce significant recruitment of Azteca ants. The induction of ant recruitment is rapid and localized to damaged leaves. Demonstration of this phenomenon indicates that plant defense in myrmecophytic plants is dynamic and not simply a function of ant presence in the general vicinity or the level of production of food bodies and nectar. Demonstration of induced responses in non-ant-plant systems has led to considerable insight into the constraints and selection pressures on plant defense (Parker 1992, Simms 1992, Agrawal and Karban 1998). Similarly, cost-benefit analyses of ant protection should consider the dynamic behavior of ants. Future studies should also consider additional cues, including the amount and spatial spread of leaf damage, and how these cues are employed by plants and ants in the induction process.

Induced responses to herbivory that attract predators have been described from many non-ant-plant systems and mechanisms whereby damaged plants attract predators of herbivores are accumulating. In the CecropiaAzteca system, multiple factors are involved in inducing ant recruitment, including: disturbance, presence of 
herbivores, volatile constituents released from damaged leaves, plant sap, and wound size. It appears that wound size may be one of the most important factors influencing the magnitude and persistence of recruitment in this system. C. obtusifolia does not appear to provide its mutualist ants with a direct or immediate reward, enticing them to recruit to sites of damage. However, the fitness of a colony of Azteca ants is likely to be tightly linked to the vigor of individual $C$. $o b$ tusifolia trees so that selection may have favored induced responses without such a direct reward. In apparently less obligate systems where food and housing of the biotic defenders are not provided by individual plants, the induced responses may be mediated by induced production of rewards such as extrafloral nectar (A. A. Agrawal and M. T. Rutter, unpublished manuscript).

\section{ACKNOWLEDGMENTS}

I am grateful for the numerous contributions of Mathew T. Rutter during the inception and initial stages of field work of this project. I also thank Rick Karban for encouraging me to continue the work and for subsequently improving many of the manuscript drafts. Beth Braker, Deborah Clark, Phyllis Coley, Sean Duffey, Lee Dyer, Brigitte Fiala, Walter Federle, Brian Fisher, Martin Heil, Bert Hölldobler, Marcel Holyoak, Steven Juliano, Louis LaPierre, Sharon Lawler, Deborah Letourneau, Bob Marquis, Chris Nice, Eric Olson, Matt Orr, Eugene Schupp, Peggy Stern, Jennifer Thaler, James Umbanhowar, and Phil Ward contributed assistance, ideas and/ or comments on earlier versions of the manuscript. Many thanks to all of you. Several anonymous reviewers also improved the manuscript. Jack Longino kindly helped with identification of the ants. Funding for this study was provided by a Graduate Fellowship from the Organization for Tropical Studies and grants from the Center for Population Biology at the University of California-Davis, the Jastro Shields Research Awards Program (U.C. Davis), the Northern California Chapter of Phi Beta Kappa, and National Science Foundation Dissertation Improvement Grant DEB-9701109.

\section{Literature Cited}

Agrawal, A. A., and R. Karban. 1998. Why induced defenses may be favored over constitutive strategies in plants. In $\mathrm{R}$. Tollrian and C. D. Harvell, editors. The ecology and evolution of inducible defenses. Princeton University Press, Princeton, in press.

Baldwin, I. T. 1990. Herbivory simulations in ecological research. Trends in Ecology and Evolution 5:91-93.

- 1994. Chemical changes rapidly induced by folivory. Pages 1-23 in E. Bernays, editor. Insect plant interactions. V. CRC Press, Boca Raton, Florida, USA.

Baldwin, I. T., and E. A. Schmelz. 1996. Immunological "memory" in the induced accumulation of nicotine in wild tobacco. Ecology 77:236-246.

Baldwin, I., and J. Schultz. 1983. Rapid changes in tree leaf chemistry induced by damage: Evidence for communication between plants. Science 221:277-279.

Baur, R., S. Binder, and G. Benz. 1991. Nonglandular leaf trichomes as short-term inducible defense of the gray alder, Alnus incana (L.), against the chrysomelid beetle, Agelastica alni L. Oecologia (Berlin) 87:219-226.

Brody, A. K., and R. Karban. 1992. Lack of a tradeoff between constitutive and induced defenses among varieties of cotton. Oikos 65:301-306.

Bruin, J., M. W. Sabelis, and M. Dicke. 1995. Do plants tap
SOS signals from their infested neighbours? Trends in Ecology and Evolution 10:167-170.

Clausen, T. P., P. B. Reichardt, J. P. Bryant, and R. A. Werner. 1991. Long-term and short-term induction in quaking aspen: related phenomena? Pages 71-83 in D. W. Tallamy and M. J. Raupp, editors. Phytochemical induction by herbivores. Wiley, New York, New York, USA.

Coleman, J. S., and A. S. Leonard. 1995. Why it matters where on a leaf a folivore feeds. Oecologia (Berlin) 101: 324-328.

Cronin, G. 1998. Between-species and temporal variation in acacia-ant-herbivore interactions. Biotropica 30:135-139.

Davidson, D. W., and B. L. Fisher. 1991. Symbiosis of ants with Cecropia as a function of light regime. Pages 289309 in C. R. Huxley and D. F. Cutler, editors. Ant-plant interactions. Oxford University Press, Oxford, UK.

Davidson, D. W., and D. McKey. 1993. The evolutionary ecology of symbiotic ant-plant relationships. Journal of Hymenoptera Research 2:13-83.

Dicke, M., T. A. Van Beek, M. A. Posthumus, N. Ben Dom, H. Van Bokhoven, and A. E. De Groot. 1990. Isolation and identification of volatile kairomone that affects acarine predator-prey interactions: involvement of host plant in its production. Journal of Chemical Ecology 16:381-396.

Dussourd, D. E., and R. F. Denno. 1994. Host range of generalist caterpillars: trenching permits feeding on plants with secretory canals. Ecology 75:69-78.

Farmer, E. E., and C. A. Ryan. 1990. Interplant communication: airborne methyl jasmonate induces synthesis of proteinase inhibitors in plant leaves. Proceedings of the National Academy of Sciences (USA) 87:7713-7716.

Fiala, B., and U. Maschwitz. 1990. Studies on the South East Asian ant-plant association Crematogaster borneensis/Macaranga: Adaptations of the ant partner. Insectes Sociaux 37:212-231.

Fisher, B. L. 1992. Facultative ant association benefits a neotropical orchid. Journal of Tropical Ecology 8:109-114.

Folgarait, P. J., and D. W. Davidson. 1995. Myrmecophytic Cecropia - antiherbivore defenses under different nutrient treatments. Oecologia (Berlin) 104:189-206.

Folgarait, P. J., H. L. Johnson, and D. W. Davidson. 1994. Responses of Cecropia to experimental removal of Müllerian bodies. Functional Ecology 8:22-28.

Fonseca, C. R. 1994. Herbivory and the long-lived leaves of an Amazonian ant-tree. Journal of Ecology 82:833-842.

Frias, R., and R. Dirzo. 1996. Effects of defoliation on Müllerian bodies in Cecropia obtusifolia in Los Tuxtlas, Veracruz. Bulletin of the Ecological Society of America 77: 150.

Harvell, C. D. 1990a. The ecology and evolution of inducible defenses. Quarterly Review of Biology 65:323-340.

. 1990b. The evolution of inducible defence. Parasitology 100:S53-S61.

Haukioja, E. 1991. Induction of defenses in trees. Annual Review of Entomology 36:25-42.

Herms, D. A., and W. J. Mattson. 1992. The dilemma of plants: to grow or defend. Quarterly Review of Biology 67:283-335.

Janzen, D. H. 1966. Coevolution of mutualism between ants and acacias in Central America. Evolution 20:249-275.

. 1969. Allelopathy by myrmecophytes: the ant Azteca as an allelopathic agent of Cecropia. Ecology 50:147-153.

- 1973. Dissolution of mutualism between Cecropia and its Azteca ants. Biotropica 5:15-28.

Jolivet, P. 1990. Relative protection of Cecropia trees against leaf-cutting ants in tropical America. Pages 251-254 in R. K. Vander Meer, K. Jaffe, and A. Cedeno, editors. Applied myrmecology: a world perspective. Westview Press, Boulder, Colorado, USA. 
erlands.

1996. Ants and plants. Backhuys, Leiden, The Neth-

Karban, R., and F. R. Adler. 1996. Induced resistance to herbivores and the information content of early season attack. Oecologia (Berlin) 107:379-385.

Karban, R., and I. T. Baldwin. 1997. Induced responses to herbivory. University of Chicago Press, Chicago, Illinois, USA.

Karban, R., and J. H. Myers. 1989. Induced plant responses to herbivory. Annual Review of Ecology and Systematics 20:331-348.

Karban, R., and C. Niiho. 1995. Induced resistance and susceptibility to herbivory: plant memory and altered plant development. Ecology 96:1220-1225.

Koptur, S. 1989. Is extrafloral nectar production an inducible defense? Pages 323-339 in J. H. Bock and Y. B. Linhart, editors. The evolutionary ecology of plants. Westview Press, Boulder, Colorado, USA.

1992. Extrafloral nectary-mediated interactions between insects and plants. Pages 81-129 in E. Bernays, editor. Insect-plant interactions IV. CRC Press, Boca Raton, Florida, USA.

Letourneau, D. K. 1983. Passive aggression: an alternative hypothesis for the Piper-Pheidole association. Oecologia (Berlin) 60:122-126.

Longino, J. T. 1989. Geographic variation and community structure in an ant-plant mutualism: Azteca and Cecropia in Costa Rica. Biotropica 21:126-132.

. 1991. Azteca ants in Cecropia trees: taxonomy, colony structure, and behaviour. Pages 271-288 in C. R. Huxley and D. F. Cutler, editors. Ant-plant interactions. Oxford University Press, Oxford, UK

Lowman, M. D. 1982. Effects of different rates and methods of leaf area removal on rain forest seedlings of coachwood (Ceratopetalum apletalum). Australian Journal of Botany 30:477-483.

Marquis, R. J. 1992. A bite is a bite is a bite? Constraints on response to folivory in Piper arieianum (Piperaceae) Ecology 73:143-152.

. 1996. Plant architecture, sectoriality and plant tolerance to herbivores. Vegetatio 127:85-97.

Mauricio, R., M. D. Bowers, and F. A. Bazzaz. 1993. Pattern of leaf damage affects fitness of the annual plant Raphanus sativus (Brassicaceae). Ecology 74:2066-2071.

McCloud, E. S., D. W. Tallamy, and F. T. Halaweish. 1995 Squash beetle trenching behaviour: avoidance of cucurbitacin induction or mucilaginous plant sap? Ecological Entomology 20:51-59.

McDade, L. A., K. S. Bawa, H. A. Hespenheide, and G. S Hartshorn. 1994. La Selva. University of Chicago Press, Chicago, Illinois, USA.

McKey, D. 1984. Interactions of the ant-plant Leonardoxa africana (Caesalpiniaceae) with its obligate inhabitants in a rainforest in Cameroon. Biotropica 16:81-99.

. 1988. Promising new directions in the study of antplant mutualisms. Pages 335-355 in W. Greuter and B. Zimmer, editors. Proceedings of the XIV International Botanical Congress. Koeltz, Konigstein/Taunus, Germany.

Naganuma, K., and H. A. Hespenheide. 1988. Behavior of visitors at insect-produced analogues of extrafloral nectaries on Baccharis sarothroides Gray. Southwestern Naturalist 33:275-286.

Niemela, P., and J. Tuomi. 1987. Does the leaf morphology of some plants mimic caterpillar damage. Oikos 50:256257.

Olson, M. M., and C. R. Roseland. 1991. Induction of the coumarins scopoletin and ayapin in sunflower by insectfeeding stress and effects of coumarins on the feeding of sunflower beetle (Coleoptera: Chrysomelidae). Environmental Entomology 20:1166-1172.
Pare, P. W., and J. H. Tumlinson. 1997. Induced synthesis of plant volatiles. Nature 385:30-31.

Parker, M. A. 1992. Constraints on the evolution of resistance to pests and pathogens. Pages 181-197 in P. G. Ayres, editor. Pests And pathogens: plant responses to foliar attack. Bios Scientific, Oxford, UK.

Passera, L., E. Roncin, B. Kaufmann, and L. Keller. 1996. Increased soldier production in ant colonies exposed to intraspecific competition. Nature 379:630-631.

Rausher, M. D., K. Iwao, E. L. Simms, N. Ohsaki, and D. Hall. 1993. Induced resistance in Ipomoea purpurea. Ecology 74:20-29.

Rehr, S. S., P. P. Feeny, and D. H. Janzen. 1973. Chemical defence in Central American non-ant-acacias. Journal of Animal Ecology 42:405-416.

Rhoades, D. 1983. Responses of alder and willow to attack by tent caterpillars and webworms: evidence for pheromone sensitivity of willows. American Chemical Society Symposium Series 208:55-68.

Risch, S. J., and F. R. Rickson. 1981. Mutualism in which ants must be present before plants produce food bodies. Nature 291:149-150.

Rocha, C. F. D., and H. G. Bergallo. 1992. Bigger ant colonies reduce herbivory and herbivore residence time on leaves of an ant-plant: Azteca muelleri vs. Coelomera ruficornis on Cecropia pachystachya. Oecologia (Berlin) 91:249-252.

Rowell, H. F. 1983. Osmilia flavolineata. Pages 750-751 in D. H. Janzen, editor. Costa Rican natural history. University of Chicago Press, Chicago, Illinois.

Schultz, J. C. 1988. Plant responses induced by herbivores. Trends in Ecology and Evolution 3:45-49.

Schupp, E. W. 1986. Azteca protection of Cecropia: ant occupation benefits juvenile trees. Oecologia (Berlin) 70: 379-385.

Shonle, I., and J. Bergelson. 1995. Interplant communication revisited. Ecology 76:2660-2663.

Shulaev, V., P. Silverman, and I. I. Raskin. 1997. Airborn signalling by methyl salicylate in plant pathogen resistance. Nature 385:718-721.

Simms, E. L. 1992. Costs of plant resistance to herbivores. Pages 392-425 in R. S. Fritz and E. L. Simms, editors. Plant resistance to herbivores and pathogens, ecology, evolution, and genetics. University of Chicago Press, Chicago, Illinois, USA.

Smith, L. L., J. Lanza, and G. C. Smith. 1990. Amino acid concentrations in extrafloral nectar of Impatiens sultani increase after simulated herbivory. Ecology 71:107-115.

Stephenson, A. G. 1982. The role of the extrafloral nectaries of Catalpa speciosa in limiting herbivory and increasing fruit production. Ecology 63:663-669.

Steward, J. L., and K. H. Keeler. 1988. Are there trade-offs among antiherbivore defenses in Ipomoea (Convolvulaceae)? Oikos 53:79-86.

Takabayashi, J., and M. Dicke. 1996. Plant-carnivore mutualism through herbivore-induced carnivore attractants. Trends in Plant Science 1:109-113.

Tallamy, D. W., and E. S. McCloud. 1991. Squash beetles, cucumber beetles, and inducible cucurbit responses. Pages 155-181 in D. W. Tallamy and M. J. Raupp, editors. Phytochemical induction by herbivores. Wiley, New York, New York, USA.

Thaler, J. S., and R. Karban. 1997. A phylogenetic reconstruction of constitutive and induced resistance in Gossypium. American Naturalist 149:1139-1146.

Tilman, D. 1978. Cherries, ants, and tent caterpillars: timing of nectar production in relation to susceptibility of caterpillars to ant predation. Ecology 59:686-692.

Turlings, T. C. J., J. H. Tumlinson, and W. J. Lewis. 1990. Exploitation of herbivore-induced plant odors by hostseeking parasitic wasps. Science 250:1251-1253.

Vasconcelos, H. L. 1991. Mutualism between Maieta gui- 
anensis Aubl., a myrmecophytic melastome, and one of its ant inhabitants: Ant protection against insect herbivores. Oecologia (Berlin) 87:295-298.

Vasconcelos, H. L., and A. B. Casimiro. 1997. Influence of Azteca alfari ants on the exploitation of Cecropia trees by a leaf-cutting ant. Biotropica 29:84-92.

Whitman, D. W., and F. J. Eller. 1990. Parasitic wasps orient to green leaf volatiles. Chemoecology 1:69-75.

Wilcox, C. 1996. Ant response to insect herbivory, and the potential for community-wide indirect effects. Bulletin of the Ecological Society of America 77:481.

Wilkinson, L., M. Hill, J. P. Welna, and G. K. Birkenbeuel. 1992. SYSTAT for Windows: Statistics, Version 5 edition. SYSTAT, Evanston, Illinois, USA.
Young, T. P. 1987. Increased thorn length in Acacia depranolobium - an induced response to browsing. Oecologia (Berlin) 71:436-438

Zangerl, A. R., and M. R. Berenbaum. 1990. Furanocoumarin induction in wild parsnip: genetics and populational variation. Ecology 71:1933-1940.

Zangerl, A. R., and M. R. Berenbaum. 1994/5. Spatial, temporal, and environmental limits on xanthotoxin induction in wild parsnip foliage. Chemoecology 5/6:37-42.

Zangerl, A. R., and C. E. Rutledge. 1996. The probability of attack and patterns of constitutive and induced defense: a test of optimal defense theory. American Naturalist 147: 599-608.

Zar, J. H. 1996. Biostatistical analysis. Third edition. Prentice Hall, Upper Saddle River, New Jersey, USA. 